\title{
KEWENANGAN KLINIS DALAM TINDAKAN PEMBEDAHAN DAN ASAS PERLINDUNGAN HUKUM BAGI PASIEN
}

\author{
Achmad Hafiedz Azis Kartamihardja, P. Lindawaty S. Sewu dan Tri Wahyu Murni S. \\ Achmad_hafiedz@yahoo.com \\ Magister Hukum Kesehatan \\ Universitas Katolik Soegijapranata Semarang
}

\begin{abstract}
ABSTRAK
Kesehatan adalah hak asasi manusia yang merupakan hak fundamental setiap warga dan harus diwujudkan dengan upaya peningkatan derajat kesehatan masyarakat yang setinggitingginya. Pasien sebagai penerima jasa pelayanan kesehatan memiliki hak untuk mendapatkan pelayanan yang aman, bermutu dan terjangkau. Untuk mendapatkan pelayanan yang bermutu, salah satunya dapat dicapai dengan pelayanan yang diberikan oleh tenaga kesehatan yang memiliki kompetensi dan kewenangan untuk melakukan pelayanan kesehatan tersebut. Dokter sebagai salah satu tenaga kesehatan yang berperan dalam peningkatan mutu pelayanan kesehatan, memerlukan kewenangan dalam melakukan upaya kesehatan. Kewenangan dokter dalam melakukan pelayanan kesehatan didapatkan dan harus sesuai dengan pendidikan dan kompetensi yang dimiliki. Dalam pelaksanaan pelayanan kesehatan, dokter dapat saja mengalami gangguan kesehatan sehingga tidak kompeten dalam melaksanakan pelayanan kesehatan serta perkembangan disiplin ilmu kedokteran menyebabkan suatu penyakit dapat ditangani oleh beberapa disiplin ilmu kedokteran yang berbeda. Hal tersebut menimbulkan pertanyaan bagaimana perlindungan terhadap pasien sehingga pasien mendapatkan pelayanan kesehatan yang terbaik, aman dan bermutu.

Penelitian ini menggunakan metode kualitatif dengan acuan penelitian hukum normatif, yang dapat digunakan berbagai pihak untuk memecahkan permasalahan berkaitan dengan asas perlindungan hukum pasien dikaitkan dengan kewenangan klinis tindakan pembedahan yang dilakukan di Rumah Sakit.

Hasil penelitian menunjukan bahwa penerapan ketentuan tentang kewenangan klinis dalam tindakan pembedahan di Rumah Sakit dilakukan melalui proses kredensial (credentialing) yang dilakukan oleh Komite Medik untuk menentukan kelayakan seseorang memperoleh kewenangan klinis (clinical privilege) dalam menjalankan tindakan medis termasuk pembedahan pada periode tertentu. Asas perlindungan hukum bagi pasien dapat dipenuhi dalam tindakan pembedahan di Rumah Sakit dengan melaksanakan tata kelola klinis yang baik (good clinical governance) bagi para tenaga klinisinya. Penerapan ketentuan mengenai kewenangan klinis (clinical privilege) dalam tindakan pembedahan di Rumah Sakit menyebabkan dapat dipenuhinya asas perlindungan hukum bagi pasien di Rumah Sakit.
\end{abstract}

Kata Kunci : Kewenangan Klinis; Tindakan Pembedahan; Asas Perlindungan Hukum 


\section{LATAR BELAKANG}

Kesehatan merupakan salah satu komponen kesejahteraan umum yang harus diusung dan diwujudkan sesuai dengan cita-cita bangsa yang tertuang dalam pembukaan Undang-Undang Dasar 1945 melalui pembangunan nasional berdasarkan Pancasila dan Undang-Undang Dasar 1945. Undang-Undang Dasar 1945 dan Konstitusi Organisasi Kesehatan Dunia (WHO) serta Undang-undang Nomor 36 Tahun 2009 tentang Kesehatan (selanjutnya disingkat UU Kesehatan), menetapkan bahwa kesehatan adalah hak asasi manusia yang merupakan hak fundamental setiap warga dan harus diwujudkan dengan upaya peningkatan derajat kesehatan masyarakat yang setinggi-tingginya. Oleh karena itu, pengembangan kesehatan menjadi esensial bagi kehidupan manusia.

Indonesia memiliki cita-cita bangsa yang tercantum dalam Pembukaan Undang-Undang Dasar 1945, yaitu melindungi segenap bangsa Indonesia, memajukan kesejahteraan umum, mencerdaskan kehidupan bangsa, dan ikut melaksanakan ketertiban dunia berdasarkan kehidupan bangsa, perdamaian abadi dan keadilan sosial. Pembangunan di bidang kesehatan sebagai salah satu upaya pembangunan nasional diarahkan guna tercapainya kesadaran, kemauan dan kemampuan untuk hidup sehat bagi setiap masyarakat agar dapat mewujudkan kesehatan yang optimal.

Sejalan dengan amanat yang tercantum dalam Undang-Undang Dasar Negara Republik Indonesia Tahun 1945, Pasal 28 ayat (1) yang menyatakan bahwa setiap orang berhak memperoleh pelayanan kesehatan, oleh karena itu pelayanan kesehatan terhadap pasien juga merupakan bagian dari hak asasi manusia. Sebagaimana tercantum sesuai dengan UU Kesehatan menempatkan dokter dan fasilitas pelayanan kesehatan sebagai pemberi jasa pelayanan kesehatan, sedangkan pasien sebagai penerima jasa pelayanan kesehatan.

Pasien sebagai penerima jasa pelayanan kesehatan memiliki hak untuk mendapatkan pelayanan yang aman, bermutu dan terjangkau seperti yang diamanatkan dalam UU Kesehatan. Untuk mendapatkan pelayanan yang bermutu, salah satunya dapat dicapai dengan pelayanan yang diberikan oleh tenaga kesehatan yang memiliki kompetensi dan kewenangan untuk melakukan pelayanan kesehatan tersebut.

Dokter sebagai salah satu tenaga kesehatan yang berperan dalam peningkatan mutu pelayanan kesehatan, memerlukan kewenangan dalam melakukan upaya kesehatan. Hal ini sesuai dengan ketentuan yang tercantum dalam UU Kesehatan, yakni tenaga kesehatan adalah setiap orang yang mengabdikan diri dalam bidang kesehatan serta memiliki pengetahuan dan/atau keterampilan melalui pendidikan di bidang kesehatan yang untuk jenis tertentu memerlukan kewenangan untuk melakukan upaya kesehatan. Kewenangan dokter dalam melakukan pelayanan kesehatan didapatkan dan harus sesuai dengan pendidikan dan kompetensi yang dimiliki.

UU Kesehatan dan Undang-Undang Nomor 29 Tahun 2004 tentang Praktik Kedokteran (selanjutnya disingkat UU Praktik Kedokteran) mengatur kewenangan klinis secara global dan bersifat administratif dengan hanya mensyaratkan dokter memiliki surat registrasi dan surat izin praktik yang berlaku selama 5 tahun. Kondisi ini dapat memunculkan beberapa persoalan, misalnya jika seorang dokter bedah yang masih dalam kurun waktu berlakunya surat registrasi dan surat izin praktik mengalami sakit stroke sehingga mengakibatkan sebelah tangannya bergetar. Secara hukum (berdasarkan UU Kesehatan dan UU Praktik Kedokteran) dokter ini masih boleh melakukan operasi, namun hal ini akan mengakibatkan pasien mendapatkan pelayanan yang beresiko tinggi sehingga dapat dikatakan tidak bermutu, dan pasien tidak terlindungi secara hukum. 
Kedokteran merupakan salah satu ilmu yang sangat luas dan di dalamnya terdapat banyak spesifikasi disiplin ilmu. Hal ini merupakan persoalan kewenangan klinis lainnya yang dapat muncul dalam dunia kedokteran. Luas dan beragamnya ilmu kedokteran mendorong setiap dokter untuk selalu mengembangkan ilmu pengetahuan tentang kedokteran itu sendiri, namun di sisi lain dapat menimbulkan tumpang tindihnya satu spesifikasi disiplin ilmu kedokteran dengan spesifikasi disiplin ilmu lainya. Sebagai contoh yaitu penanganan pasien bibir sumbing yang dapat ditangani oleh dokter spesialis bedah plastik karena mendapatkan pelatihan dalam pendidikannya juga diberikan kewenangan oleh kolegium, begitu pula dengan dokter spesialis bedah mulut. Contoh lain adalah penanganan pasien keganasan faring, yang dapat ditangani oleh dokter spesialis bedah onkologi dan dokter spesialis THT-KL, karena keduanya mendapatkan pendidikan mengenai keganasan faring serta mendapatkan kewenangan dari masing-masing kolegium.

Hal ini menjadi masalah terutama di Rumah Sakit besar seperti RSUP Dr. Hasan Sadikin Bandung, dimana di dalamnya terdapat multi profesi dokter dari berbagai spealisasi hingga subspesialisasi, sehingga kemungkinan terjadinya tumpang tindih kewenangan dalam menangani pasien sering terjadi. Rumah Sakit yang merupakan institusi pelayanan kesehatan bagi masyarakat dengan karakteristik tersendiri yang dipengaruhi oleh perkembangan ilmu pengetahuan kesehatan, kemajuan teknologi, dan kehidupan sosial ekonomi masyarakat yang harus tetap mampu meningkatkan pelayanan yang lebih bermutu dan terjangkau oleh masyarakat agar terwujud derajat kesehatan yang setinggi-tingginya.

Tindakan pembedahan merupakan salah satu pelayanan kesehatan yang beresiko tinggi dan rawan untuk terjadinya perbuatan melawan hukum, serta hasil dari tindakan pembedahan dapat terlihat jelas apakah tindakan pembedahan tersebut berhasil atau tidak, sehingga dibutuhkan peraturan untuk mengatur tindakan pembedahan.

Untuk menjawab permasalahan-permasalahan tersebut, Rumah Sakit sebagai institusi pelayanan kesehatan yang diharuskan tetap mampu meningkatkan pelayanan yang lebih bermutu, melalui Komite Medis Rumah Sakit dapat mengatur kewenangan klinis yang di dalamnya menuliskan tugas dan wewenang tiap dokter melalui Peraturan Internal Rumah Sakit (Hospital By Laws) sehingga diharapkan dapat memberikan kepastian hukum dan perlindungan bagi pasien ataupun dokter itu sendiri. Pengaturan tersebut didasarkan salah satunya kepada perlindungan dan keselamatan pasien, seperti yang diamanatkan dalam Undang-Undang Nomor 44 Tahun 2009 tentang Rumah Sakit (selanjutnya disingkat UU Rumah Sakit), serta didasarkan kepada Keputusan Menteri Kesehatan Nomor 722/MENKES/SK/VI/2002 tentang Pedoman Peraturan Internal Rumah Sakit (selanjutnya disebut Kepmenkes Pedoman Peraturan Internal Rumah Sakit) dan Keputusan Menteri Kesehatan Republik Indonesia Nomor 631/MENKES/SK/IV/2005 tentang Pedoman Peraturan Internal Staf Medis (selanjutnya disebut Kepmenkes Pedoman Peraturan Internal Staf Medis).

\section{PERMASALAHAN}

1. Dalam penelitian ini dapat dirumuskan beberapa rumusan masalah yaitu sebagai berikut:

2. Bagaimana penerapan ketentuan tentang kewenangan klinis dalam tindakan pembedahan di Rumah Sakit?

3. Bagaimana asas perlindungan hukum bagi pasien yang dapat dipenuhi dalam tindakan pembedahan di Rumah Sakit?

4. Bagaimana ketentuan tentang kewenangan klinis dalam tindakan pembedahan yang menyebabkan dipenuhinya asas perlindungan hukum bagi pasien di Rumah Sakit? 


\section{METODE PENELITIAN}

Metode penelitian yang digunakan dalam penelitian ini adalah deskriptif analitis dengan metode pengumpulan data yang dipergunakan adalah studi kepustakaan. Adapun metode pendekatan yang digunakan adalah metode pendekatan yuridis normatif, yaitu mengkaji hukum yang dilakukan dengan cara meneliti bahan pustaka atau sekunder belaka yang bersumber dari bahan hukum primer, sekunder dan tersier.

\section{GAMBARAN KEWENANGAN KLINIS DAN HAK ORGAN RUMAH SAKIT DALAM MENENTUKAN KEWENANGAN KLINIS}

Kewenangan klinis adalah kewenangan untuk melakukan tindakan medis tertentu dalam lingkungan sebuah rumah sakit tertentu berdasarkan penugasan yang diberikan oleh kepala Rumah Sakit. Jika dilihat dari bentuk pemberian kewenangan, kewenangan klinis merupakan kewenangan delegatif yang diberikan oleh Rumah sakit, melalui komite medik sebagai organ pemberi kewenangan, kepada dokter selaku pemberi jasa pelayanan kesehatan. Sehingga jika pada pelaksanaan pelayanan kesehatan terdapat tindakan yang melawan hukum, maka tanggung jawab dan tanggung gugat jatuh kepada penerima kewenangan. Namun dalam kaitan dengan tanggung jawab rumah sakit, maka pada prinsipnya rumah sakit bertanggung jawab secara perdata terhadap semua kegiatan yang dilakukan oleh tenaga kesehatan sesuai dengan bunyi Pasal 1367 (3) KUHPerdata. Menurut Pasal 1367 KUHPerdata, apabila dokter melakukan wanprestasi atau perbuatan melawan hukum, tuntutan ganti kerugian tidak hanya diajukan kepada dokter saja, tapi juga dapat ditujukan kepada pihak Rumah Sakit.

Kewenangan klinis perlu dibedakan dari kewenangan dokter sebagai tenaga kesehatan yang terkandung dalam UU Kesehatan, maupun UU Praktik Kedokteran. Kewenangan yang terkandung dalam UU Kesehatan maupun UU Praktik Kedokteran melekat dan secara langsung digariskan/berasal dari undang-undang setelah dokter tersebut melalui pendidikan dan dianggap kompeten dengan telah terbitnya STR dan SIP, sehingga kewenangan ini asli dan tidak dapat dibagi-bagikan kepada orang lain. Kewenangan berdasarkan undang-undang ini bersifat atributif sehingga tanggung jawab dan tanggung gugat berada pada subjek hukum sebagaimana tertera dalam peraturan dasarnya. Sedangkan kewenangan klinis yang dimaksud dalam penelitian ini merupakan kewenangan khusus yang hanya diterapkan di Rumah Sakit. Seorang dokter yang memiliki kewenangan atributif, belum tentu mendapatkan kewenangan klinis tertentu di Rumah Sakit tempat ia bekerja, dan seorang dokter dapat saja memiliki kewenangan klinis tertentu di Rumah Sakit yang satu, namun tidak memiliki kewenangan klinis yang sama di Rumah Sakit lainnya.

Kewenangan klinis di sebuah Rumah Sakit merupakan hasil dari proses kredensial yang dilakukan oleh Komite Medik melalui sub-komite kredensial. Proses Kredensial (Credentialing) merupakan proses evaluasi oleh suatu rumah sakit terhadap seseorang untuk menentukan apakah yang bersangkutan layak diberi kewenangan klinis (clinical privilege) untuk menjalankan tindakan medis tertentu dalam lingkungan rumah sakit tersebut untuk suatu periode tertentu. Menanggapi masalah ini dibutuhkan suatu pedoman kredensial dan kewenangan klinis di rumah sakit yang diharapkan dapat dijadikan acuan dasar dalam kegiatan kredensial oleh rumah sakit di Indonesia. Pedoman ini dibutuhkan oleh pihak rumah sakit dalam melaksanakan kredensial tenaga medis dengan baik serta bagi perlindungan pasiennya. Pedoman disusun oleh Tim Penyusun Pedoman Mekanisme Kredensial Dokter di Rumah Sakit berdasarkan SK Pengurus Pusat PERSI No. 41/SK/PP.PERSI/II/2008 dengan mengacu pada kelaziman praktik perumah sakitan yang baik di negara maju, antara lain JCAHO. Pedoman ini dimaksudkan agar menjadi panduan bagi rumah sakit di Indonesia untuk melakukan kredensial para tenaga medis dengan baik, benar, dan dapat dipertanggungjawabkan. 
Proses utama kredensial ditujukan untuk mengendalikan kewenangan untuk melakukan tindakan medis yang terinci (delineation clinical privilege) bagi setiap dokter yang bertumpu pada tiga tahap. Pertama, praktisi medis melakukan permohonan untuk memperoleh kewenangan klinis dengan metode self assessment. Kedua, mitra bestari mengkaji dan memberikan rekomendasi tindakan medis yang diajukan oleh pemohon. Ketiga, kepala rumah sakit menerbitkan surat penugasan (clinical appointment) berdasarkan rekomendasi dari mitra bestari yang berlaku untuk periode tertentu. Secara periodik, dokter akan melalui proses rekredensial saat masa berlaku surat penugasannya berakhir, di mana tiga proses inti tersebut akan berulang.

\section{a. Tahap pertama berupa permohonan untuk memperoleh kewenangan klinis}

Setiap tenaga medis mengajukan permohonan kepada kepala rumah sakit untuk melakukan tindakan medis. Tenaga medis tersebut mengisi beberapa formulir yang disediakan rumah sakit, antara lain daftar tindakan medis yang ingin dilakukannya sesuai dengan bidang keahliannya. Tenaga medis tersebut memilih tindakan medis yang tertera dalam formulir daftar tindakan medis tersebut dengan cara mencontreng, dan menyerahkan salinan semua dokumen yang dipersyaratkan kepada rumah sakit. Syarat-syarat tersebut meliputi juga kesehatan fisik dan mental untuk melakukan tindakan medis tertentu. Setelah formulir lengkap, rumah sakit menyerahkannya kepada Komite Medik untuk ditindak lanjuti.

\section{b. Tahap kedua berupa kajian mitra bestari}

Komite Medik menugaskan subkomite kredensial untuk memproses permohonan tersebut. Subkomite kredensial menyiapkan mitra bestari yang berjumlah sekitar 4 hingga 6 orang sesuai dengan bidang keahlian yang akan dinilai. Mitra bestari tersebut tidak harus anggota subkomite kredensial, bahkan dapat berasal dari luar rumah sakit bila diperlukan.

Para mitra bestari yang bertugas tersebut dapat terdiri dari beberapa bidang spesialis sesuai dengan kewenangan klinis yang diminta. Misalnya, bila seorang dokter mengajukan permohonan untuk melakukan tiroidektomi, maka mitra bestari yang dipilih dapat terdiri dari para spesialis bedah umum, bedah onkologi, dan spesialis THT-KL. Dengan demikian kelompok mitra bestari tersebut dapat berbeda untuk setiap tenaga medis yang mengajukan permohonan kewenangan klinis.

Mitra bestari mengkaji setiap tindakan medis yang diajukan oleh pemohon. Pengkajian setiap tindakan medis yang diajukan oleh pemohon tersebut dilakukan secara objektif didasarkan pada suatu buku putih ( white paper). Sebuah buku putih untuk tindakan medis tertentu yang memuat syarat-syarat kapan seorang dokter dianggap kompeten melakukan tindakan medis tersebut. Misalnya, dalam buku putih untuk melakukan tiroidektomi, seorang dokter harus menjalani pendidikan bedah dasar, pelatihan-pelatihan tertentu, dan telah menangani sejumlah kasus tertentu dalam kurun waktu tertentu. Berdasarkan buku putih (white paper) tersebut mitra bestari dapat merekomendasi atau menolak permohonan tindakan medis yang diajukan. Selain menilai kompetensi, mitra bestari juga menilai kemampuan pemohon berdasarkan kesehatan fisik dan mental untuk setiap tindakan medis yang diajukan. Rumah sakit mempersiapkan sarana dan prasarana dan panel dokter untuk melakukan uji kesehatan fisik dan mental tersebut.

Pada akhir proses kredensial, mitra bestari merekomendasikan sekelompok tindakan medis tertentu yang boleh dilakukan oleh pemohon di rumah sakit tersebut. Selanjutnya Komite Medik mengkaji kembali rekomendasi tersebut dan mengadakan beberapa modifikasi bila diperlukan dan selanjutnya diserahkan kepada kepala rumah sakit. 


\section{c. Tahap ketiga berupa penerbitan surat penugasan}

Kepala rumah sakit menerbitkan surat penugasan kepada tenaga medis pemohon berdasarkan rekomendasi tersebut. Kepala rumah sakit dapat saja meminta Komite Medik untuk mengkaji ulang rekomendasi tersebut bersama pihak menejemen rumah sakit bila dianggap perlu. Surat penugasan tersebut memuat daftar sejumlah kewenangan klinis untuk melakukan tindakan medis bagi tenaga medis pemohon. Setiap tenaga medis dalam satu bidang spesialisasi tertentu dapat saja memiliki daftar kewenangan klinis yang berbeda dengan sejawatnya dengan bidang spesialisasi yang sama. Suatu tindakan medis tertentu di rumah sakit hanya boleh dilakukan oleh dokter yang telah memiliki surat kewenangan klinis berdasarkan surat penugasan. Daftar kewenangan klinis seorang tenaga medis dapat dimodifikasi setiap saat. Seorang tenaga medis dapat saja mengajukan tambahan kewenangan klinis yang tidak dimiliki sebelumnya dengan mengajukan permohonan kepada kepala rumah sakit. Selanjutnya Komite Medik akan melakukan proses kredensial khusus untuk tindakan tersebut, dan akan memberikan rekomendasinya kepada kepala rumah sakit. Namun sebaliknya, kewenangan klinis tertentu dapat saja dicabut, baik untuk sementara atau seterusnya karena alasan tertentu seperti akan diuraikan pada bab berakhirnya kewenangan klinis.

\section{PENERAPAN ASAS PERLINDUNGAN HUKUM BAGI PASIEN DI RUMAH SAKIT}

Asas perlindungan hukum bagi pasien merupakan salah satu roh/jiwa dalam hukum kesehatan, yang bersumber dari hak asasi manusia seperti yang tercantum dalam UndangUndang Dasar Negara Republik Indonesia Tahun 1945, Pasal 28 ayat (1) yang menyatakan bahwa setiap orang berhak untuk hidup sehat dan memperoleh pelayanan kesehatan. Oleh sebab itu, pelayanan kesehatan yang bermutu, aman dan terjangkau merupakan hal yang penting dan perlu untuk dicapai demi menjunjung hak asasi manusia.

Perwujudan dari asas perlindungan hukum bagi pasien, dilakukan dengan 2 cara yaitu dengan membuat peraturan (by giving regulation), yang bertujuan untuk memberikan dan menjamin hak dan kewajiban seluruh subjek hukum, tidak hanya pasien namun juga dokter dan rumah sakit, serta menegakkan peraturan (by the law enforcement) yang telah ditetapkan.

Dengan disahkannya UU Rumah Sakit, keselamatan pasien telah menjadi issue sentral. Salah satu upaya menuju keselamatan pasien tersebut adalah dengan mencegah terjadinya kecelakaan medis akibat inkompetensi tenaga medis di rumah sakit. Penjelasan Pasal 29 ayat (1) butir r. UU Rumah Sakit menetapkan bahwa dalam statuta rumah sakit (Medical Staff By Laws) diatur tentang kewenangan klinis (Clinical Privilage) setiap tenaga medis di rumah sakit.

Undang-undang tentang Rumah Sakit menuntut setiap rumah sakit untuk melindungi keselamatan pasien, antara lain dengan melaksanakan tata kelola klinis yang baik (good clinical governance) bagi para klinisinya. Tata kelola klinis yang baik (Good Clinical Governance) adalah penerapan fungsi manajemen klinis yang meliputi kepemimpinan klinik, audit klinis, data klinis, risiko klinis berbasis bukti, peningkatan kinerja, pengelolaan keluhan, mekanisme monitor hasil pelayanan, pengembangan profesional, dan akreditasi rumah sakit. Tiga aspek penting di dalam clinical governance, antara lain kualitas berstandar nasional berlaku bagi seluruh organisasi kesehatan (dalam hal ini dengan menerapkan prosedur operasi standar), mekanisme untuk menjaga standar pelayanan yang tinggi (termasuk didalamnya memastikan long-life learning dan regulasi profesi yang sesuai seperti pada penetapan mengenai kewenangan klinis), dan sistem yang efektif untuk memantau implementasi kerangka tersebut, seperti tolak ukur dari indikator klinis dan penilaian kerja sistem. 
Salah satu faktor krusial dalam keselamatan pasien adalah kewenangan dokter untuk melakukan tindakan medis yang saat itu tidak dikendalikan dengan adekuat oleh Komite Medik rumah sakit. Dalam hal seorang dokter kurang kompeten dalam melakukan tindakan medis tertentu karena sebab apapun, belum ada mekanisme yang mencegah dokter untuk melakukan tindakan medis tersebut di rumah sakit. Pada gilirannya kondisi ini dapat menimbulkan kecelakaan pada pasien.

Demi menjaga keselamatan pasien dari tindakan medis yang dilakukan oleh dokter yang kurang kompeten, rumah sakit perlu mengambil langkah-langkah pengamanan dengan cara pemberian kewenangan klinis melalui mekanisme kredensial yang dilaksanakan oleh Komite Medik. Beberapa pihak yang terkait dengan upaya ini adalah Kolegium Kedokteran Indonesia dan Komite Medik rumah sakit. Kolegium Kedokteran Indonesia dapat menjadi acuan untuk menentukan lingkup dan jenis-jenis kewenangan klinis bagi setiap cabang ilmu kedokteran. Komite Medik akan menentukan jenis-jenis kewenangan klinis bagi setiap dokter yang bekerja di rumah sakit berdasarkan kompetensinya melalui mekanisme kredensial. Dengan terkendalinya tindakan medis di setiap rumah sakit maka pasien lebih terlindungi dari tindakan medis yang dilakukan oleh dokter yang tidak kompeten.

\section{HUBUNGAN KEWENANGAN KLINIS DALAM TINDAKAN PEMBEDAHAN DAN ASAS PERLINDUNGAN HUKUM BAGI PASIEN}

Tindakan pembedahan merupakan salah satu pelayanan kesehatan yang beresiko tinggi dan rawan untuk terjadinya perbuatan melawan hukum, serta hasil dari tindakan pembedahan dapat terlihat jelas apakah tindakan pembedahan tersebut berhasil atau tidak, sehingga dibutuhkan peraturan untuk mengatur tindakan pembedahan di Rumah Sakit. Salah satu upaya rumah sakit dalam menjalankan tugas dan tanggung jawabnya untuk menjaga keselamatan pasiennya adalah dengan menjaga standar profesi dan kompetensi para dokter yang melakukan tindakan medis terhadap pasien di rumah sakit. Upaya ini dilakukan dengan cara mengatur agar setiap tindakan medis yang dilakukan terhadap pasien hanya dilakukan oleh tenaga medis yang benar-benar kompeten. Persyaratan kompetensi ini meliputi dua komponen, (1) komponen kompetensi keprofesian medis yang terdiri dari pengetahuan, ketrampilan, dan prilaku profesional; dan, (2) komponen kesehatan yang meliputi kesehatan fisik dan mental.

Brevet merupakan pengakuan tentang keahlian seorang dokter oleh kolegium suatu cabang ilmu kedokteran tertentu. Dalam lingkup tindakan pembedahan, walaupun seorang dokter telah mendapatkan brevet spesialisasi dari kolegium ilmu kedokteran yang bersangkutan, namun rumah sakit wajib melakukan verifikasi kembali kompetensi seseorang untuk melakukan tindakan pembedahan dalam lingkup spesialisasi tersebut, hal ini dikenal dengan istilah credentialing. Proses credentialing ini dilakukan dengan dua alasan utama. Alasan pertama, banyak faktor yang mempengaruhi kompetensi setelah seseorang mendapatkan brevet spesialisasi dari kolegium. Perkembangan ilmu di bidang kedokteran untuk suatu tindakan medis tertentu sangat pesat, sehingga kompetensi yang diperoleh saat menerima brevet bisa kadaluarsa, bahkan dapat dianggap sebagai tindakan yang tidak aman bagi pasien. Selain itu, lingkup suatu cabang ilmu kedokteran tertentu senantiasa berkembang dari waktu-kewaktu sehingga suatu tindakan yang semula tidak diajarkan pada penerima brevet pada periode tertentu, dapat saja belakangan diajarkan pada periode selanjutnya, bahkan dianggap merupakan suatu kemampuan yang standar. Hal ini mengakibatkan bahwa sekelompok dokter yang menyandang brevet tertentu dapat saja memiliki lingkup kompetensi yang berbeda-beda. Alasan kedua, keadaan kesehatan seseorang dapat saja menurun akibat penyakit tertentu atau bertambahnya usia sehingga mengurangi keamanan tindakan medis yang dilakukannya. Kompetensi fisik dan mental dinilai melalui uji kelaikan kesehatan baik fisik maupun mental. Tindakan verifikasi kompetensi profesi medis tersebut oleh rumah sakit disebut sebagai mekanisme credentialing, dan hal ini dilakukan demi keselamatan pasien. 
Setelah seorang dokter dinyatakan kompeten melalui suatu proses kredensial, rumah sakit menerbitkan suatu ijin bagi yang bersangkutan untuk melakukan serangkaian tindakantindakan medis di rumah sakit tersebut, hal ini dikenal sebagai kewenangan klinis (Clinical Privilege). Tanpa adanya kewenangan klinis (Clinical Privilege) tersebut seorang dokter tidak diperkenankan untuk melakukan tindakan medis di rumah sakit tersebut. Luasnya lingkup kewenangan klinis (clinical privilege) sesorang dokter spesialis dapat saja berbeda dengan koleganya dalam spesialisasi yang sama, tergantung pada ketetapan Komite Medik tentang kompetensi untuk melakukan tiap tindakan medis oleh yang bersangkutan berdasarkan hasil proses kredensial. Dalam hal tindakan medis seorang dokter membahayakan pasien maka kewenangan klinis (Clinical Privilege) seorang dokter dapat saja dicabut sehingga tidak diperkenankan untuk melakukan tindakan medis tertentu dilingkungan rumah sakit tersebut. Pencabutan kewenangan klinis (Clinical Privilege) tersebut dilakukan melalui prosedur tertentu yang melibatkan Komite Medik.

Kewajiban rumah sakit untuk menetapkan kewenangan klinis (clinical privilege) tersebut telah diatur dengan tegas dalam UU Rumah Sakit. Dalam UU Rumah Sakit Pasal 29 ayat (1) butir $r$ telah ditetapkan bahwa setiap rumah sakit wajib menyusun dan melaksanakan hospital by laws, yang dalam penjelasan undang-undang tersebut ditetapkan bahwa setiap rumah sakit wajib melaksanakan tata kelola klinis yang baik (Good Clinical Governance). Hal ini harus dirumuskan oleh setiap rumah sakit dalam peraturan staf medis Rumah Sakit (medical staff by laws) antara lain diatur kewenangan klinis (clinical privilege). Kelemahan rumah sakit dalam menjalankan fungsi kredensial akan menimbulkan tanggung jawab hukum bagi rumah sakit dalam hal terjadi kecelakaan tindakan medis. Setiap rumah sakit wajib melindungi pasiennya dari segala tindakan medis yang dilakukan oleh setiap dokter di rumah sakit tersebut, hal ini dikenal sebagai the duty of due care.

\section{KESIMPULAN}

Berdasarkan hasil pembahasan berkaitan dengan kewenangan klinis dalam tindakan pembedahan dikaitkan dengan asas perlindungan hukum bagi pasien dapat ditarik suatu kesimpulan sebagai berikut:

1. Penerapan ketentuan tentang kewenangan klinis dalam tindakan pembedahan di Rumah Sakit dilakukan melalui proses kredensial (credentialing) berupa proses evaluasi oleh suatu rumah sakit, dalam hal ini organ rumah sakit yang bertangung jawab melakukannya adalah Komite Medik, untuk menentukan kelayakan seseorang untuk memperoleh kewenangan klinis (clinical privilege) dalam menjalankan tindakan medis termasuk pembedahan pada periode tertentu.

2. Asas perlindungan hukum bagi pasien yang dapat dipenuhi dalam tindakan pembedahan di Rumah Sakit dengan melaksanakan tata kelola klinis yang baik (good clinical governance) bagi para klinisinya. Pemenuhan asas kepercayaan dalam perlindungan hukum bagi pasien yang menuntut setiap dokter di rumah sakit bekerja dalam koridor kewenangan klinis yang ditetapkan oleh kepala rumah sakit.

3. Ketentuan tentang kewenangan klinis dalam tindakan pembedahan menuntut setiap dokter di rumah sakit bekerja sesuai dengan kewenangan yang telah diberikan sehingga dapat terselenggaranya tata kelola klinis yang baik di Rumah Sakit. Penerapan ketentuan mengenai kewenangan klinis dalam tindakan pembedahan di Rumah Sakit menyebabkan dapat dipenuhinya asas perlindungan hukum bagi pasien di Rumah Sakit, sedangkan bila tidak dilakukannya penerapan ketentuan mengenai kewenangan klinis dalam tindakan pembedahan di Rumah Sakit menyebabkan tidak dapat dipenuhinya asas perlindungan hukum bagi pasien di Rumah Sakit. Penerapan ketentuan kewenangan klinis dapat pula memberikan perlindungan kepada dokter selaku pemberi jasa pelayanan kesehatan. 
SARAN

Berdasarkan kesimpulan yang telah diambil dalam penelitian ini maka dapat dirumuskan saran saran yaitu :

1. Mengingat pentingnya penerapan ketentuan kewenangan klinis (clinical privilege) di Rumah Sakit dalam pencapaian pelindungan hukum bagi pasien dan dokter, maka diperlukannya sosialisasi dan pengawasan mengenai penerapan ketentuan kewenangan klinis (clinical privilege) kepada seluruh pengelola Rumah Sakit.

2. Perlu adanya informasi dan edukasi kepada pasien mengenai kewenangan klinis dan hak pasien sehingga munculnya kepercayaan dalam pemenuhan perlindungan hukum bagi pasien melalui berbagai media informasi di Rumah Sakit seperti panflet-panflet, dan papan informasi

3. Peraturan mengenai kewenangan klinis merupakan salah satu peraturan yang sangat penting dalam pemenuhan perlindungan hukum bagi pasien, namun belum ada peraturan secara khusus yang mendetail membahas mengenai kewenangan klinis. Begitu pula dengan tindakan pembedahan dilihat dari segi hukum yang spesifik belum ada peraturan yang mengaturnya, yang lebih kepada inform consent dan rekam medisnya sehingga disarankan agar dirancang dan ditetapkan suatu aturan yang mengatur khusus tentang kewenangan klinis dan tindakan medis pembedahan dari aspek hukum beserta peraturan untuk kewenangan klinisnya.

\section{DAFTAR PUSTAKA}

Departemen Kesehatan Republik Indonesia, Pedoman Peraturan Internal Rumah Sakit (Hospital Bylaws), Jakarta, 2002.

Departemen Kesehatan Republik Indonesia, Pedoman Peraturan Internal Staf Medis(Medical Staff Bylaws) di Rumah Sakit, Jakarta, 2005.

Perhimpunan Rumah Sakit Seluruh Indonesia, Pedoman Kredensial dan Kewenangan Klinis (Clinical Priviledge) di Rumah Sakit. Jakarta, 2009.

Undang-Undang Dasar 1945

Undang-Undang No. 29 Tahun 2004 Tentang Praktek Kedokteran.

Undang-Undang No.36 Tahun 2009 Tentang Kesehatan.

Undang-Undang No. 44 Tahun 2009 Tentang Rumah Sakit

Peraturan Menteri Kesehatan Nomor 290/MENKES/PER/III/2008 Tentang Persetujuan Tindakan Kedokteran

Peraturan Menteri Kesehatan Nomor 755/MENKES/PER/IV/2011 tentang Penyelenggaran Komite Medik di Rumah Sakit

Keputusan Menteri Kesehatan RI No. 722/MENKES/SK/VI/2002 Tentang Pedoman Peraturan Internal Rumah Sakit

Keputusan Menteri Kesehatan RI No. 631/MENKES/SK/IV/2005 Tentang Pedoman Peraturan Internal Staf Medis 